\author{
Ананьєва Є. A., \\ кандидат юридичних наук, \\ доцент кафедри правового забезпечення господарської діяльності \\ фбакультету № 6 \\ Харківського національного університету внутрішніх справ
}

\title{
ОБ’ЄДНАНА ТЕРИТОРІАЛЬНА ГРОМАДА ЯК СУБ'ЄКТ ФІНАНСОВИХ ПРАВОВІДНОСИН
}

\begin{abstract}
Анотація. У статті на основі аналізу наукових поглядів і норм чинного законодавства детально охарактеризована об'єднана територіальна громада як суб'єкт фінансових правовідносин. 3'ясовуєтеся статус об'єднаної територіальної як суб'єкта фінансових правовідносин. Відзначаються основні елементи, які характеризують статус об'єднаної територіальної громади, а саме їі правоздатність. Висвітлено основні думки з приводу визначення правосуб'єктності об'єднаної територіальної громади. Розглянуто основні елементи правосуб'єктності: правоздатність, дієздатність, деліктоздатність. Наголошено на тому, що в основі правосуб'єктності, зокрема, й об'єднаної територіальної громади покладена загальна правоздатність суб'єктів права, що дає
\end{abstract} змогу охарактеризувати територіальну громаду як юридичну особу зі всіма притаманними їй ознаками, такими як організаційна єдність, майнова відокремленість, що дає ій змогу виступати від свого імені в цивільному обігу, позивачем і відповідачем у суді. Розглянуто, як саме та завдяки чому виникає й змінюється фінансова правосуб'єктність об'єднаних територіальних громад. Досліджено взаємозв'язок між суб'єктом фінансових правопорушень і відповідальністю за можливе порушення своїх обов'язків як складника фінансової правосуб'єктності. Розглянуті основні види фінансових правопорушень, а саме: податкові, бюджетні, правопорушення у сфері валютного регулювання, правопорушення у сфері готівкового грошового обігу. Доведено, що ці правопорушення можуть застосовуватися не до об'єднаної територіальної громади, а тільки до окремих посадових осіб. Наголошено на тому, що чітке законодавче визначення фінансової правосуб'єктності об'єднаних територіальних громад може й повинно мати місце, зокрема доцільно сформулювати в нормативно-правових актах поняття «правосуб'єктність об'єднаних територіальних громад» і форми безпосередньої участі об'єднаних територіальних громад у вирішенні питань фінансової діяльності. Розвиток і збільшення фінансової самостійності об'єднаних територіальних громад не може розглядатися як потенційна загроза політичній та економічній системі держави. Навпаки, поліпшення соціально-економічного середовища об'єднаних територіальних громад $є$ потужним фундаментом для укріплення державності України загалом.

Ключові слова: об'єднана територіальна громада, фінансові правовідносини, правосуб'єктність, правоздатність, дієздатність, фінансово-правовий статус, фінансова діяльність.

Постановка проблеми. Важливим фактором, що характеризує територіальну громаду як суб'єкта фінансових правовідносин, $є$ їі правовий статус як учасника правовідносин, що сьогодні розглядається крізь призму правосуб'єктності.
Фундатор фінансового права Л.К. Воронова наполягала на тому, що суб'єкт фінансових правовідносин, на відміну від суб'єкта фінансового права, - це реальний учасник правових відносин, який характеризується правосуб' єктністю [1, с. 77]. Зазвичай у правовій літературі зміст правосуб'єктності розглядається як сукупність правоздатності, дієздатності й деліктоздатності, разом узятих [2, с. 340]. О.Ф. Скакун зміст правосуб'єктності або правового статусу конкретної особи чи організації розкриває через комплекс прав та обов'язків, які має кожен суб'єкт права внаслідок дії того чи іншого закону, незалежно від участі його в тих або інших правовідносинах [3, с. 354]. Отже, правосуб'єктність, яка складається зі здатності мати права й обов'язки та дієздатності, тобто реальної участі у фінансових правовідносинах, а також і відповідальність за своїми зобов' язаннями є необхідними ознаками суб'єкта як учасника правовідносин, зокрема фінансових.

Мета статті - на підставі чинного законодавства й думок науковців щодо поняття «правосуб'єктність» охарактеризувати фінансово-правовий статус об'єднаної територіальної громади (далі - ОТГ) як учасника фінансової діяльності на місцевому рівні.

Виклад основного матеріалу дослідження. Наукові думки щодо правосуб'єктності ОТГ потребують розгляду правового статусу територіальної громади, оскільки ОТГ сьогодні не розглядається в законодавстві відокремлено від територіальних громад як базового визначення цього суб'єкта правовідносин. У працях науковців зустрічаються різні точки зору стосовно правосуб' єктності територіальних громад і її змісту. На думку O. Скакун, територіальна громада має правоздатність, оскільки $€$ сукупністю громадян - носіїв права, об'єднаних за територіальною ознакою, має відповідні юридичні можливості для реалізації цього права [3, с. 141]. Як зазначає Р. Стефанчук, територіальні громади можуть брати участь у майнових та особистих немайнових відносинах, однак, як і юридична особа, можуть бути наділені тільки тими особистими немайновими правами, які не суперечать їхній правовій природі, зокрема на найменування, ділову репутацію, інформацію тощо [4, с. 324]. 0.О. Первомайський наголошував на невирішеності питання обсягу цивільної правоздатності територіальної громади [5, с. 69]. О. Сохацька зазначає, що зміст правоздатності фізичних осіб та організацій складається з прав та обов'язків, що не можуть бути в територіальної громади та їі органів [6, с. 390]. Варто погодитися 3 думками науковців про певну відмінність правоздатності територіальних громад від правоздатності фізичних осіб і правоздатності юридичних осіб приватного права. Проте фінансові правовідносини мають як характерні 
риси, що притаманні всім правовідносинам, так і специфічні, серед яких - об'єкт правовідносин, суб'єктний склад і повноваження задіяних учасників фінансових правовідносин. Об' єкт фінансових правовідносин - фінанси, тобто відносини з формування, розподілу, використання та контролю централізованих і децентралізованих фондів коштів, а також суб'єктний склад. Однією стороною фінансових правовідносин є суб'єкт владних повноважень в особі органів державної влади, органів місцевого самоврядування, а також і територіальних громад, проте, з іншого боку, підвладний суб' єкт має права, які є й обов'язками водночас. Суб'єкт фінансового права, як визначено в дослідженнях, - це особа, учасник фінансових відносин, яка за своїми особливостями фактично може бути носієм суб' єктивних прав та обов'язків [1, с. 76]. Отже, ОТГ, як і територіальна громада, характеризується у фінансових правовідносинах колом особливих прав та обов'язків щодо формування, розподілу, використання й контролю фінансових ресурсів, які є в розпорядженні та які становлять іiі фінансову правосуб'єктність.

Зазвичай у правовій літературі до складу правосуб'єктності зараховують такі елементи, як правоздатність, дієздатність і деліктоздатність. Так, Н. Матузов зазначає, що юридична властивість бути суб'єктом будь-яких передбачених законом прав і обов'язків є загальною, постійною й невід' ємною якістю всіх суб' єктів права, що належить усім і кожному, оскільки правоздатність виражає саме цю всезагальну якість, вона також не може не мати загального характеру для всіх галузей права [7, с. 74-75]. Отже, в основі правосуб'єктності, зокрема, й ОТГ покладена загальна правоздатність суб'єктів права.

Дієздатність, як визначають теоретики права, - це визнана нормами об' єктивного права здатність суб' єкта самостійно, своїми свідомими діями здійснювати юридичні права й обов'язки [8, с. 309]. Наголошується на тому, що дієздатність - це здатність суб'єкта правовідносин своїми діями брати на себе обов' язки, а також використовувати свої права, тобто це можливість реалізувати правоздатність [9, с. 341]. Деліктоздатність у наукових працях розглядається як здатність суб'єкта права нести відповідальність за свої протиправні вчинки [3, с. 342]. Отже, дієздатність ОТГ виявляється в реалізації встановлених законом прав та обов'язків, зокрема в діяльності обраних нею органів влади, тобто органів місцевого самоврядування, а також у їх відповідальності за виконання своїх прав та обов'язків.

У цьому аспекті необхідно вести мову про відповідальність ОТГ в особі іiї органів управління, яку можна охарактеризувати як відповідальність за ступінь реалізації інтересів i потреб ОТГ [10, с. 145]. Дійсно, деліктоздатність повинна мати місце в правовому статусі територіальних громад, зокрема й об'єднаних, яка виявляється в ії майновій відповідальності за зобов'язаннями.

У статті 169 Цивільного кодексу України зазначається, що територіальні громади діють у цивільних відносинах на рівних правах $з$ іншими учасниками цих відносин. Також ця стаття надає територіальним громадам право створювати юридичні особи публічного права (комунальні підприємства, спільні комунальні підприємства, навчальні заклади тощо) та юридичні особи приватного права (підприємницькі товариства тощо), брати участь у них на загальних підставах. Згідно зі ст. 172, безпосередніми суб' єктами набуття й реалізації цивільних прав та обов'язків від імені територіальних громад є органи місцевого самоврядування в межах їхньої компетенції. Які й інші суб'єкти цивільних правовідносин, територіальні громади несуть майнову відповідальність за своїми зобов'язаннями. Територіальні громади відповідають за своїми зобов'язаннями своїм майном, крім майна, на яке, відповідно до закону, не може бути звернено стягнення (ст. 175) [11].

Отже, територіальні громади мають відокремлене майно, у тому числі кошти, які знаходяться в їхній комунальній власності. При цьому управління майном, що є в комунальній власності, здійснюють безпосередньо територіальна громада й утворені нею органи місцевого самоврядування. Безпосередньо територіальні громади не можуть набувати та реалізовувати цивільні права й обов' язки інакше, ніж через утворювані ними органами місцевого самоврядування.

Підсумовуючи наведені положення цивільного законодавства стосовно правового статусу територіальних громад, у тому числі й об'єднаних, у сфері цивільних правовідносин, можемо підтримати думки тих учених, які наголошують, що для того, щоб бути учасником цивільних правовідносин, громада, як і будь-яке колективне утворення, повинна відповідати ознакам, які притаманні суб' єктам цивільного права, а отже, $€$ підстави вважати, що їй приманні всі ознаки юридичної особи [12, с. 311-312], а саме: організаційна єдність, майнова відокремленість, що дає їм змогу виступати від свого імені в цивільному обігу, позивачем і відповідачем у суді [13, с. 168].

Отже, доцільно погодитися з думками науковців-цивілістів, що територіальна громада, у тому числі й об'єднана, має всі ознаки юридичної особи публічного права.

Існують думки науковців щодо недоцільності проекції правоздатності, що набувають суб'єкти цивільних правовідносин на інші види правовідносин. Наприклад, Л. Грось наголошує на тому, що юридична особа є суб'єктом передусім цивільного права, а правосуб'єктність юридичної особи в галузях трудового й фінансового права має похідний характер [14, с. 33]. Варто вказати на хибність цієї думки. Загальний правовий статус ОТГ як суб'єкта будь-яких правовідносин як необхідного елементу включає й спеціальний правовий статус, що дає їй змогу брати участь у фінансових правовідносинах, адже неможливо уявити правовідносини за участю ОТГ поза межами фінансової діяльності. Тому можна повністю підтримати думку вченого, що фінансово-правовий статус територіальної громади є невід'ємною частиною загалом правового статусу територіальної громади, що виражає особливості їі правового стану як суб'єкта фінансового права, тобто як суб' єкта, що діє на стадіях мобілізації, розподілу та використання фінансових ресурсів для задоволення потреб економічного й соціального розвитку свого регіону [15, с. 117]. Характеризуючи фінансові відносини, А. Нестеренко визначає їх як урегульовані фінансово-правовими нормами відносини, що виникають, змінюються та припиняються в процесі формування, розподілу, перерозподілу й використання централізованих і децентралізованих фінансових ресурсів, мають майновий характер, і підкреслює, що основною метою фінансових правовідносин $є$ фінансове забезпечення суспільних потреб $[15$, с. 7$]$.

Отже, фінансово-правові відносини за участю ОТГ мають публічний характер, оскільки спрямовані на забезпечення інтересів громадян, надання соціальних, адміністративних та інших послуг членам відповідної громади на рівні, що є не нижчим від установленого на загальнодержавному рівні та не нижчим за той, що мав місце до об'єднання. 
На думку вчених, фінансова правосуб’'єктність громади пов'язана 3 реалізацією правоздатності. Так, М. Препелиця вважає, що територіальна громада має здатність безпосередньо виражати та здійснювати свою правову волю у сфері фінансової діяльності, тобто має фінансову правосуб'єктність. Фінансова правоздатність - це можливість територіальної громади мати фінансові обов'язки та права (наприклад, територіальна громада має право формувати дохідну частину місцевого бюджету за рахунок власних джерел). Фінансова дієздатність - це можливість територіальної громади здійснювати свої фінансові обов'язки та права, що вже має місце в конкретних правовідносинах [14, с. 116]. Вочевидь, автор наголошує на фінансовій дієздатності й фінансовій правоздатності саме органів місцевого самоврядування як представників відповідних територіальних громад.

У працях учених уточнюється сутність складників правосуб์'єктності. Ю. Оніщик розкриває фінансову правосуб'єктність юридичних осіб через такі складники, як фінансові: правоздатність, дієздатність і деліктоздатність. Фінансова правоздатність - це здатність суб'єкта фінансового права мати права й нести обов'язки у сфері, пов'язаній зі здійсненням державою та органами місцевого самоврядування фінансової діяльності. Фінансова дієздатність - це здатність суб'єкта фінансового права своїми діями набувати та здійснювати права й обов'язки, які передбачені фінансовим законодавством. Фінансова деліктоздатність - це здатність суб'єкта фінансового права за порушення своїх обов'язків нести відповідальність у випадках, передбачених фінансовим законодавством [15]. Підтримуючи цю думку, варто вказати, що здатність нести відповідальність за порушення своїх обов'язків як складник фінансової правосуб'єктності тісно пов'язана 3 можливістю бути суб'єктом фінансових правопорушень.

У сфері фінансової діяльності О. Задихайло виокремлює такі види правопорушень: податкові (порушення встановленого порядку взяття на облік (ресстрації) у сфері контролюючих органів (ст. 117 Податкового кодексу України)), бюджетні (включення недостовірних даних до бюджетних запитів (ст. 116 Бюджетного кодексу України)), правопорушення у сфері валютного регулювання (здійснення операцій з валютними цінностями без одержання генеральної чи індивідуальної ліцензії Національного банку України), правопорушення у сфері готівкового грошового обігу (порушення граничної суми розрахунків готівкою) тощо [16, с. 88]. Види можна продовжити, проте як видно 3 наведеного, певна низка фінансових правопорушень стосується й сфери діяльності місцевого самоврядування.

Серед суб'єктів фінансових правопорушень у вітчизняній науки фінансового права В. Нагребельний виділяе такі: загальні суб̆'єкти (визначаються нормами фінансового права) та спеціальні суб'єкти (особа, яка безпосередньо зазначена у фінансовому законі). Загалом коло суб'єктів відрізняється залежно від виду фінансових правовідносин [17, с. 116]. Видається, що ОТГ як жителі сіл, селищ, міст, що добровільно об'єдналися, не може бути безпосереднім суб' єктом фінансового правопорушення.

Отже, деліктоздатність ОТГ як складник фінансової правосуб์'єктності не призводить до включення ії до кола суб'єктів, що несуть відповідальність за фінансові правопорушення. Суб'єктом таких правопорушень, що мали місце у фінансових правовідносинах за участю ОТГ, $є$ конкретні посадові особи відповідних органів місцевого самоврядування.
Отже, можна підтримати думку тих учених, які наголошують на нетотожності понять «суб̆'єкт фінансових правовідносин» і «суб̆'єкт фінансового правопорушення». Зокрема, О. Дмитрик до суб'єкта фінансових правовідносин зараховує індивідуально визначеного реального учасника конкретних фінансових правовідносин, а до суб'єкта фінансового правопорушення - учасника фінансових правовідносин, який порушив норму права, що регулює цей вид правовідносин [18, с. 46]. Проте існують протилежні думки. Як зазначає К. Ровинська, громади мають відповідати за ефективність використання ресурсів, наданих із централізованих фондів, зокрема бюджету, сформованого за участю всіх громадян держави. Відповідальність територіальної громади за ступінь реалізації власних інтересів не обмежується несприятливими наслідками у вигляді низького рівня соціальних благ. Юридичне значення в цьому випадку має те, що територіальна громада в разі прийняття необміркованих рішень, невмілої чи пасивної поведінки, неефективного використання наданих коштів позбавлена права вимагати від держави забезпечення соціальними благами та послугами [19, с. 384-385]. Остання думка видається доволі спірною, оскільки неефективність використання в тому числі й наданих коштів здійснюється насамперед відповідними органами місцевого самоврядування та їх посадовими особами.

Неефективне використання коштів громади зазвичай $€$ наслідком не стільки недбалого ставлення до них з боку територіальної громади як населення певної території країни, скільки наслідком протиправних, зокрема й корупційних, дій обраних ними посадовців. Тому в будь-якому разі зменшення рівня соціального забезпечення мешканців певної частини держави внаслідок названих дій або навіть службової недбалості посадових осіб органів місцевого самоврядування $€$ прикрим фактом недостатньої обізнаності населення щодо діяльності відповідних суб'єктів, низької громадянської та правової свідомості тощо.

Однак юридичним наслідком неефективного використання наданих коштів органами місцевого самоврядування не можуть бути санкції від держави щодо позбавлення населення, що становить відповідну територіальну громаду та $\epsilon$ частиною населення єдиної країни, права на забезпечення мінімальних соціальних гарантій, що надані Конституцією та законами України для всіх іiі громадян та осіб, що на законних засадах перебувають на її території.

ОТГ має можливість брати участь у фінансових правовідносинах як безпосередньо, так i через органи місцевого самоврядування, що нею утворені. Зазвичай така участь здійснюється обраними ОТГ органами місцевого самоврядування. Безпосередня участь об'єднаної територіальної громади може проявлятися, зокрема, у формі проведення місцевих референдумів 3 питань формування, розподілу й використання відповідних місцевих коштів.

У статті 143 Конституції України визначено, що територіальні громади села, селища, міста безпосередньо або через утворені ними органи місцевого самоврядування управляють майном, що $є$ в комунальній власності; затверджують програми соціально-економічного та культурного розвитку й контролюють їх виконання; затверджують бюджети відповідних адміністративно-територіальних одиниць і контролюють ї виконання; установлюють місцеві податки та збори відповідно до закону; забезпечують проведення місцевих референдумів 
і реалізацію їх результатів; утворюють, реорганізовують і ліквідовують комунальні підприємства, організації й установи, а також здійснюють контроль за їхньою діяльністю; вирішують інші питання місцевого значення, зараховані законом до їхньої компетенції.

Разом із тим безпосередня участь ОТГ у фінансових правовідносинах сьогодні залишається неможливою. Законодавством регламентована участь саме представницьких органів ОТГ як суб'єктів фінансових правовідносин, які діють від їхнього імені й у їхніх інтересах. Проведення місцевих референдумів можливо лише в порядку та за умов, визначених законодавством, яке не визначає коло фінансово-правових питань, що можуть бути розглянуті на відповідному референдумі. Отже, сьогодні суб'єктом фінансових правовідносин $€$ представницькі органи ОТГ, а саме відповідна сільська, селищна чи міська рада.

Висновки. ОТГ $є$ публічною юридичною особою, що утворена в результаті реорганізації сільських, селищних, міських рад, обраних територіальними громадами, що об'єдналися шляхом їх приеднання до юридичної особи: сільської, селищної, міської ради, розміщеної в адміністративному центрі ОТГ. ОТГ є учасником фінансової діяльності, оскільки має повноваження 3 формування, розподілу та використання відповідних фондів коштів.

Специфікою фінансової правосуб'єктності ОТГ є таке:

- матеріальна та фінансова основа діяльності, яку становлять рухоме й нерухоме майно, кошти, земля та інші природні ресурси, тобто ті, що перебували в комунальній власності сільської, селищної, міської ради, що розміщена в адміністративному центрі ОТГ;

- майнові, грошові, а також природні ресурси, що перейшли ОТГ за правонаступництвом від територіальних громад, які об'єдналися, з дня набуття повноважень сільською, селищною, міською радою, обраною такою ОТГ;

- можливість самостійного прийняття рішень стосовно набуття й виконання майнових та інших фінансових зобов'язань;

- обов'язок відповідати за зобов' язаннями своїм майном, на яке за законом може бути звернено стягнення;

- можливість бути засновником юридичних осіб не лише публічного, а й приватного права тощо.

Фінансово-правовий статус ОТГ є ключовим елементом іiі загального правового статусу, визначає іiі права й обов'язки, а також відповідальність, яка набувається в процесі виникнення, зміни та припинення відносин у сфері формування, розподілу й використання фінансових ресурсів 3 метою забезпечення інтересів і потреб членів ОТГ.

ОТГ як суб̆'єкт фінансових правовідносин має відповідну фінансову правоздатність і дієздатність, які виникають із дня набуття повноважень сільською, селищною, міською радою, обраною ОТГ.

ОТГ може стати потужним суб'єктом фінансових правовідносин за рахунок розширення сфер іiі участі в цих відносинах, надання фінансової самостійності щодо формування, розподілу та витрачання власних фінансових ресурсів. Це зумовлено різноплановістю правової природи ОТГ, оскільки, з одного боку, ОТГ є носієм публічної влади, що діє в межах, визначених законодавством, представляс інтереси й фактично діє від імені населення, що передало повноваження вирішення питань відповідним органам місцевого самоврядування, а з іншого боку,
ОТГ - юридична особа публічного права, що повинна мати широкі можливості для задоволення інтересів і потреб мешканців відповідної території.

\section{Jimepamypa:}

1. Воронова Л.К. Фінансове право України : підручник. Київ : Прецедент ; Моя книга, 2006. 448 с.

2. Ц Цивільне право України: Академічний курс : підручник : у 2 т. / за заг. ред. Я.М. Шевченко. 2-е вид., доп. і перероб. Київ : Видавничий Дім «Ін Юре», 2006. Т. 1 : Загальна частина. 696 с.

3. Скакун О.Ф. Теорія держави і права (Енциклопедичний курс) : підручник. 2-е вид., перероб. і доп. Харків : Еспада, 2009. 752 с.

4. Цивільне право : навчальний посібник / за заг. ред. Р.О. Стефанчука. Київ : Наукова думка, 2004. 756 с.

5. Первомайський О.О. Участь територіальної громади у цивільних правовідносинах. Харків : Страйд, 2005. 184 с.

6. Сохацька О. Деякі проблеми організаційно;правової форми органів місцевого самоврядування як юридичних осіб. Ефективність державного управління : збірник наукових праць. Львів, 2005. Вип. 8. С. 387-394.

7. Матузов Н.И. Субъективные права граждан СССР / под общ. ред. И.Е. Фарбер. Саратов : Изд-во Саратовского университета, 1966. $190 \mathrm{c}$.

8. Хропанюк В. Н.Теория государства и права : учебник для высших учебных заведений / под ред. профессора В.Г. Стрекозова. Москва : Интерстиль, Омега-Л, 2006. 382 с.

9. Загальна теорія держави і права : підручник / за ред. М.В. Цвіка, О.В. Петришина. Харків : Право, 2009. 584 с.

10. Чапала Г.В. Місцеве самоврядування в системі публічної влади: теоретико-правовий аналіз : монографія. Харків : Право, 2006. $224 \mathrm{c}$.

11. Цивільний кодекс України від 02.04.2020 № 435-IV. Вiдомості Верховної Ради України (ВВР). 2003. № 40-44. Ст. 356.

12. Цивільне право України. Загальна частина : підручник / за ред. О.В. Дзери, Н.С. Кузнєцової, Р.А. Майданика. 3-є вид., перероб. і допов. Київ : Юрінком Інтер, 2010. 976 с.

13. Кузнецова Н. Поняття й класифікація юридичних осіб у цивільному праві України: теорія і практика. Сучасні проблеми приватного права : збірник наукових праць / відп. ред. Н.С. Кузнецова, Р.О. Стефанчук. Київ : ВГО «Асоціація цивілістів України». Кам'янець-Подільський : ТОВ «Друкарня Рута», 2012. С. 159-176.

14. Грось Л. Участие публично-правовых образований в отношениях собственности: гражданско-правовые проблемы. Хозяйство $u$ право. 2001. № 5. С. 29-35.

15. Оніщик Ю.В. Особливості фінансової правосуб'єктності юридичних осіб. URL: https://dspace.uzhnu.edu.ua/jspui/bitstream/lib/96. pdf.

16. Задихайло О.А. Актуальні проблеми фінансово-правової відповідальності в Україні. Право : збірник наукових праць Харківського національного педагогічного університету імені Г.С. Сковороди. 2018. Вип. 28. С. 85-90.

17. Нагребельний В.П., Чернадчук В.Д., Сухонос В.В. Фінансове право України. Загальна частина : навчальний посібник для студ. вищих навч. закл. / Ін-т держави і права ім. В.М. Корецького НАН України ; Укр. акад. банківської справи Нац. банку України. Суми : Університет, Книга, 2004. 320 с.

18. Дмитрик О.А. Содержание и классификация финансовых правоотношений / под ред. Н.П. Кучерявенко. Харьков : Легас, 2004. $160 \mathrm{c}$.

19. Ровинська К.І. Правосуб'єктність територіальної громади: теоретико-правовий аспект. Науковий вісник Академії муніиипального управління. Серія «Управління». 2013. Вип. 3. С. 380-388. URL: file://C:/Users/7272 1/AppData/Local/Temp/Nvamu_upravl_ 2013_3_48.pdf. 
Ananieva E. The united territorial community as a subject of financial legal relations

Summary. In this article, based on the analysis of scientific views and norms of the current legislation, the unified territorial community is described in detail as the subject of financial legal relations. Determines the status of the united territorial community as a subject of financial relations. The basic elements that characterize the status of a united territorial community, namely its legal capacity, are identified. The main thoughts about determining the legal personality of the united territorial community are covered. The basic elements of legal personality such as legal capacity, capacity and tort are considered. It is emphasized that the basis of legal personality, including the united territorial community, is the general legal capacity of the subjects of law, which allows to characterize the territorial community as a legal entity with all its inherent characteristics, namely: organizational unity, property separation, enabling them to act on their behalf in civil, claimant and defendant cases in court. The way in which the financial legal personality of the united territorial communities arises and changes is considered. The relationship between liability for breach of their duties as a component of financial legal personality and the possibility of being subject to financial offenses is considered. The basic types of financial offenses are considered, namely: tax, budgetary, offenses in the field of currency regulation, offenses in the sphere of cash circulation. It is proved that these offenses can not be applied to the united territorial community, only to individual officials. It is emphasized that a clear legislative definition of the financial legal personality of the united territorial communities can and should take place, in particular, it is appropriate to define both the forms of direct involvement of the united territorial communities in solving financial activity issues and the range of relevant issues. The development and increase of the financial capacities of the united territorial communities cannot be considered as a potential threat to the political and economic system of the state.

Key words: united territorial community, financial legal relations, legal personality, legal capacity, legal capacity, financial and legal status, financial activity. 